\title{
Exposure as Collected Intended Dose Regimen
}

National Cancer Institute

\section{Source}

National Cancer Institute. Exposure as Collected Intended Dose Regimen. NCI

Thesaurus. Code 6117485.

A treatment plan that specifies the amount, schedule, and the duration of the collected exposure. 